\title{
Teachers' And Students' Attitudes Towards Integrating Environmental Education in the Secondary School Curriculum for Managing Environmental Degradation in Machakos Sub County, Kenya
}

Timothy Mandila Chikati,

$\mathrm{PhD}$ candidate, Catholic University of Eastern Africa (CUEA)

\begin{abstract}
:
This study investigated implementation of integrated environmental education in the secondary school curriculum for managing environmental degradation in Machakos Sub-County. The study was thus informed by Fullan's theory of educational change (2007). The theory views the implementation of IEE programme through lenses of four independent variables identified as need; clarity; complexity; quality and practicality on the one hand and teachers' and students' levels of environmental awareness, knowledge, skills, attitudes and participation as dependent variables on the other hand. These variables network with local factors and external factors as intervening variables to determine the IEE implementation process. The study employed cross-section survey design under the quantitative approach. Probability sampling designs were used to select participants for the study. The target population of this study was public secondary schools, teachers and form 4 students from Machakos Sub-County. Stratified and simple random sampling techniques we reemployed in sampling secondary schools, teachers and students. Questionnaires were used for data collection. Quantitative data were analysed using simple descriptive statistics. Overall study findings demonstrated that both teachers' and students' attitudes towards integrated environmental education in the secondary school curriculum were fairly positive though not adequate enough for effective implementationof IEE in the school curriculum hence, the unyielding environmental degradation in Machakos Sub-County. The study recommended that The Ministry of Education and the relevant urgencies such as KICD, DQA Sand KNEC work jointly with school managers to draw an action plan to reinforce and intensify teachers' and students' levels of environmental attitudes through pre-service and in-service training, workshops and seminars on contemporary environmental issues. It is also recommended that studies are undertaken to understand those impediments that impede change in teachers' and students' environmental attitudes so that useful and practical interventions can be identified.
\end{abstract}

Key words: teachers and students' attitudes; commitment to implementation of environmental education; secondary school curriculum and environmental degradation.

\section{Introduction}

The planet earth where life in all its forms is nurtured is definitely undergoing environmental change on an unmatched scale. Environmental degradation and the depletion of natural resources are on the rise at an alarming rate (International Fund for Agricultural Development, 2007). This ensued from anthropocentric or rational utilitarian considerations that humans are justifiably significant and therefore nature is a resource to be used by and for the people. Due to the fragility of nature's balance the planet earth is now under unfathomable threat putting scientists and governments in a state of anxiety. It is alleged that the concern for environmental problems and the quality of the environment has never been as high as it is now (Mwanza, 2016 as cited in Palmer, 1998) "Perhaps the rise of concern is associated with pressing environmental challenges that people encounter in their daily lives" p.7 (Chowdhury 2015). For example Waswa (2012) contends that land degradation remains a major threat to the world's ability to meet the growing demand for food and other environmental services. This is a critical global fright because land is one of the resources 
where reducing supply threatens our capacity to feed a growing world population estimated to be over 9 billion by 2043 (United Nations, 2015).

At a regional level, Chronicle (2014) observes that 70\% of Africa's 500 million people who depend directly on environment for livelihood will be affected. At the national level, the costs of climate change in Kenya could be equivalent to $2.6 \%$ of the country's GDP each year by 2030 (The Republic of Kenya, NEMA, 2013).

At the local level, Machakos Sub-County which is a microcosm of Kenya's ASAL areas is undergoing continuous land degradation (Kryptone Consulting Limited, 2012) and climate change scenarios that are a menace to the livelihoods of the residents. Study findings by Baaru, Gachene, Onwonga, Mbuvi \& Gathaara (2010) in Kathekakai Location of the Sub-County show that vast land has been heavily degraded and therefore this remains a major threat to the provision of environmental services and the ability to meet the growing demand for food for the residents. Similarly, Masila, 2016 (as cited in Ellenkamp, 2004) asserts that Kakayuni, Kyangala and Kinoi sub-locations in Kalama Division suffer comparable fatal outcome of land degradation affecting agricultural land use negatively.

Faced with environmental problems of such enormity, environmental education (EE) in the secondary school syllabus has generally been considered an important intervention strategy. Catching them young is an effective way of creating environmental awareness and this might result in eco-soldiers in their later lives (Mwanza, 2016 as cited in Strong 1998). Mwanza (2016) further observes that "there has been a strong support for the development of Environmental Education as one of the most critical elements of an all-out attack on the world's environmental crisis" pp 1-2

Environmental education aims to help people develop positive attitudes, emotions, thoughts or behaviors that increase their sensitivity towards the environment (Erten, Özdemir \& Güler, 2003). Environmental education is crucial to prepare environmentally literate students who, as future citizens, would play an active role in protecting the environment through making informed decisions and taking environmental friendly actions (UNESCO-UNEP 1991).

The ultimate aim of environmental education is to motivate citizens to act individually and collectively in an environmentally conscious manner that balances the social, economic, and ecological needs of today without compromising those of the future (Ugulu, Sahin, \& Baslar, 2013 as cited in Hungerford, Peyton, Wilke, 1980; Yorek, Ugulu, Sahin, Dogan, 2010)

The need for and relevance of EE was already made explicit in the major Global conferences held by the United Nations Educational, Scientific and Cultural Organisation (UNESCO) in the 1970s and 1980s ( Álvarez-García, Sureda-Negre, and Comas-Forgas, 2015). Since that time, many nations have implemented various types of EE programs within schools (Kelani, 2015). Kenya like many other countries integrated environmental considerations in the secondary school curricula to ensure efficient management of the environment and its natural resources. However it has to be noted that there are various procedures for incorporating EE into the school system, especially social science curricula (Adedayo \& Olawebo, 1997). For instance comprehensive integrative frameworks proposed for EE integration included: interdisciplinary approach by which EE content was slotted into the curriculum as a single subject, although as observed by Kelani (2015) this model was rarely used because the curriculum was already congested. For that reason multidisciplinary or infusion approach was recommended in the Kenyan situation because it did not necessitate major changes to the curriculum that was already in place.

By multidisciplinary (infusion) approach EE contents were blended into other diverse subjects relying on teachers' own creativity, resourcefulness and attitude towards such infusion. For example, incorporation of environmental content, skills, and values into subjects that already had deep seated EE content (carrier subjects) required that the teachers carefully analyze appropriate entry points in the subject area and incorporate the associated EE content and skills. On the other hand, infusion of EE content into non-carrier subjects such as mathematics, languages, art, music and dance with no definite EE content required teachers' own innovativeness to incorporate the EE content.

Null (2011) believes that the successful implementation of curriculum depends on the meaning and attitudes that teachers give towards the curriculum. Environmental attitudes were considered important because having an idea about environmental attitudes of people provides important clues for development of effective EE strategies (ÜNAL, 2008). According to (Kelani, 2015) teachers tended to teach more EE if they held more favourable attitudes toward EE. Given that teachers should demonstrate pro-environmental behaviour and attitudes if they are to integrate EE effectively in their teaching (Esa, 2010) it appeared 
logical to explore teachers' environmental attitudes in Machakos Sub County. In the final analysis, teachers are the ones who have to make integration happen (Jenny \& Hanrahan, 2002). Teachers are most influential in educating children and teenagers to be leaders of tomorrow in protecting the environment (Esa, 2010). Teachers are accordingly instrumental factors in the formation of these attitudes (Said, Ahmadun, Paim, Masud 2003; Kandýr, Yurt, Cevher-Kalburan, 2012).

It also appeared plausible to investigate students' environmental attitudes because according to Ugulu, Sahin, and Baslar (2013) studies suggest a link between students' attitudes toward environment and their level of interest in learning about environmental topics. Koskei (2013) further observes that positive attitudes do not only influence the willingness of people to implement but also the pupil's willingness to learn. Environmental quality in the future is depending on the students at present as they are future leaders later involved in decision making (Hassan, Abd Rahman, \& Abdullah, nd). Therefore according to Hassan, et al (nd) students' decisions and actions will determine the status of the environment in the future. This view accords with that put forward by Keaney (nd, as cited in Diogenes Laërtius) that "The foundation of every state is the education of its youth." Studying students' attitudes towards environment may provide help towards the solution of environmental problems (Ugulu, Erkol, 2013). From this perspective, it is important to examine student attitudes .... and the development of planned behaviors (Bennett, Lubben \& Hogarth 2007; Kahriman-Ozturk, Olgan, Tuncer, 2012).

According to Upadhyay (nd) environmental attitude...is a psychological tendency expressed by evaluating the natural environment with some degree of favour or disfavor. The relationship between environmental attitudes and personal behaviour changes, however, is complex (Jan Činčera, 2015). Many researchers have shown that both awareness and attitudes are prerequisites of pro-environmental behavior (Hashemzadeh, 2016) and therefore according to (Prati, Albanesi, \& Pietrantoni, 2017) environmental attitudes are one of the several psychological factors that strongly influence pro-environmental behaviour. A person who has positive environmental attitudes, mostly have a tendency to participate in several environmental activities (ÜNAL, 2008 as cited inT1kka, Kuitunen, Tynys, 2000). According to McGuire (2015) there is evidence that under certain conditions, attitudes can be reasonably predictive of behaviour.

However, Ajzen and Fishbein (2005) argue that the attitude-behavior relationship is not direct but mediated by other factors such as values. For example, people's desires may be stronger than their beliefs, and thus have a negative attitude towards sustainability (Keleş, 2017). According to Myers, Boyes, Stanisstreet (2004) studies suggest that the relationship between cognitive and affective attributes is weak and nonlinear. In the same vein Taskin (2009) showed that students' attitudes toward environmental concerns vary depending on the type of school, gender, education level, and the views of parents, profession, and household income. Wright and Klÿn, (1998) further post that even though attitudes could be measured quantitatively; they were ineffective predictors of behaviour.

Due to this unclear attitude-behavior gap, Greve (2001) lamented that social psychologists have essentially abandoned the idea of direct and straightforward relation between an attitude and a behavior. Given the conflicting views about attitudes of people, the attitudes of teachers and students as frontline curriculum implementers need to be investigated because this would expose the mislaid link in the study of environmental attitudes and will encourage future research studies with more comprehensive viewpoints on promotion of environmental attitudes that may engage potential and current environmental problems such as environmental degradation.

\section{Statement of the problem}

Despite the transformative power of teachers' and students' environmental attitudes to implementation of integrated environmental education (IEE), there have been a series of outcries that the effect of attitudes on the practice of IEE in Machakos Sub County has remained dismal and therefore according to (Toili, 2007; Odeke, 2009; Kimaryo, 2011) environmental degradation continues to defy the popular educational solutions. It is somewhat disturbing that previous related studies have tended to focus on improving students' cognitive achievement, whilst students' attitudes tended to be ignored (Bachtiar, Zubaidah, Corebima, \& Indriwati, 2018). Besides, the studies about teachers who function as a bridge in establishing attitudes and in acquiring knowledge, have been very scarce (Vlaardingerbroek and Taylor, 2007; Özden, 2008; Engin, 2003; Altın, 2001; Erol, 2005; Erten, 2005).

While there has been limited research carried out to understand environmental attitudes of people (Upadhyay, nd), most studies engage in conflicting views about people's attitudes (Poddar 2009; Kimaryo 
2011; Odeke 2009; Ajipoye, \& Silo, 2008; Jian 2004; Bhandari \& Abe, 2000). Plombon (2011) further observes that values and attitudes towards the environment are drastically shifting.

This raises serious questions; what are secondary school teachers' environmental attitudes towards integration of environmental education (IEE) in the school curriculum in Machakos Sub County? What are secondary school students' environmental attitudes towards integration of environmental education (IEE) in the school curriculum in Machakos Sub County? Given the critical environmental crisis happening in the Sub County, the current study therefore aims to fill the gap in research by investigating secondary school teachers' and students' environmental attitudes to enhance and guarantee effective implementation of IEE as a measure of managing environmental degradation in Machakos Sub County.

\section{Research questions}

i. What are secondary school teachers' environmental attitudes towards integration of environmental education (IEE) in the school curriculum in Machakos Sub County?

ii. What are secondary school students' environmental attitudes towards integration of environmental education (IEE) in the school curriculum in Machakos Sub County?

\section{Theoretical framework}

This study investigated teachers' and students' attitudes towards integration of environmental education in the secondary school curriculum for managing environmental degradation in Machakos Sub County. The study was grounded in the theory of educational change by Fullan (2007) According to Fullan (2007) success or failure of a programme such as IEE is determined by three categories of factors namely characteristics of change ( need, clarity, complexity, quality \& practicality) interacting with pertinent local factors ( leadership of County Education Board [CEB], school principals' perceptions, creativity \& collegial cooperation) and external factors (Ministry of Education \& its agencies) as illustrated in Table 1

Table 1: Factors that Influence Educational Change

\begin{tabular}{|l|l|l|}
\hline Characteristics of Change & Local Factors & External Factors \\
\hline Need for change & County Education Board, & Ministry of \\
Clarity about goals and objectives & School Principals' & Education \& \\
Complexity of the programme & perceptions, creativity & its agencies \\
Quality and practicality of the program & $\&$ collegial cooperation & /KICD \\
& & \\
\hline
\end{tabular}

Source: Adapted from Fullan (2007)

Need involves whether the implementers of integrated environmental education (IEE) see the value in this programme. For example, do the teachers as line implementers of IEE indisputably value the programme? Do they get a genuine incentive or concrete proof that the programme will be of use in terms of improved students' knowledge, skills, values, attitudes, concern and participation in environmental sustainability? For that reason, successful implementation of IEE is dependent on whether the felt need of all the key players is creditable enough to place IEE above all the other programmes. According to Fullan (as cited in Hammonds, 2002) "If people cannot find meaning in any reform it cannot have any impact" Therefore to gather support for IEE, teachers and administrators will need to be convinced that it is worth the time, money and effort (Westmoreland-King, 2012).

Conversely, clarity involves communicating goals and objectives of EE effectively for easy understanding by the intended programme implementers from the start. Fullan (2007) notes, "It should be clarified what the teachers should do differently" p.89. Short of this may cause anxiety and frustration among the teachers on how the programme translates into practice.

According to Fullan (2007) complexity is the "level of difficulty..." p.90 of an innovation such as IEE. Complexity therefore is the degree to which implementation of IEE is perceived as difficult to understand. In support of the theory of change, Rogers (2003) contends that undue complexity of an innovation is an obstacle to programme adoption. This implies that processes involved in implementation of a new programme such as IEE should be simplified to such a degree that they are understood by all interested parties to enhance effective implementation.

Quality and practicality of a programme (Table 1) involve the degree of commitment directed at the initiative in terms of resources and time (Fullan, 2001). This implies that all stakeholders (local and external) 
need to direct a great deal of their attention to implementation of IEE in terms of the requisite resources (Quality) and set timelines to accomplish each identified task. Without resources effective implementation of any new programme would be counterproductive. According to Fullan's Theory of Educational Change (2007) support (Quality) in terms of the amount of resource (human and material) deserves clear-headed attention in programme implementation.

In the context of the theory of educational change practicality implies how pragmatic the implementation process of the new programme is and how well this fits in with the teachers' current work conditions. For example, do the teachers have the time to practice the implementation of the programe in a safe setting? If teachers are already jammed with other activities, practicality of the IEE programme would be sacrificed especially when the teachers are expected to implement several other programmes simultaneously.

\section{Conceptual Framework}

The Conceptual framework for this study is articulated in figure 1

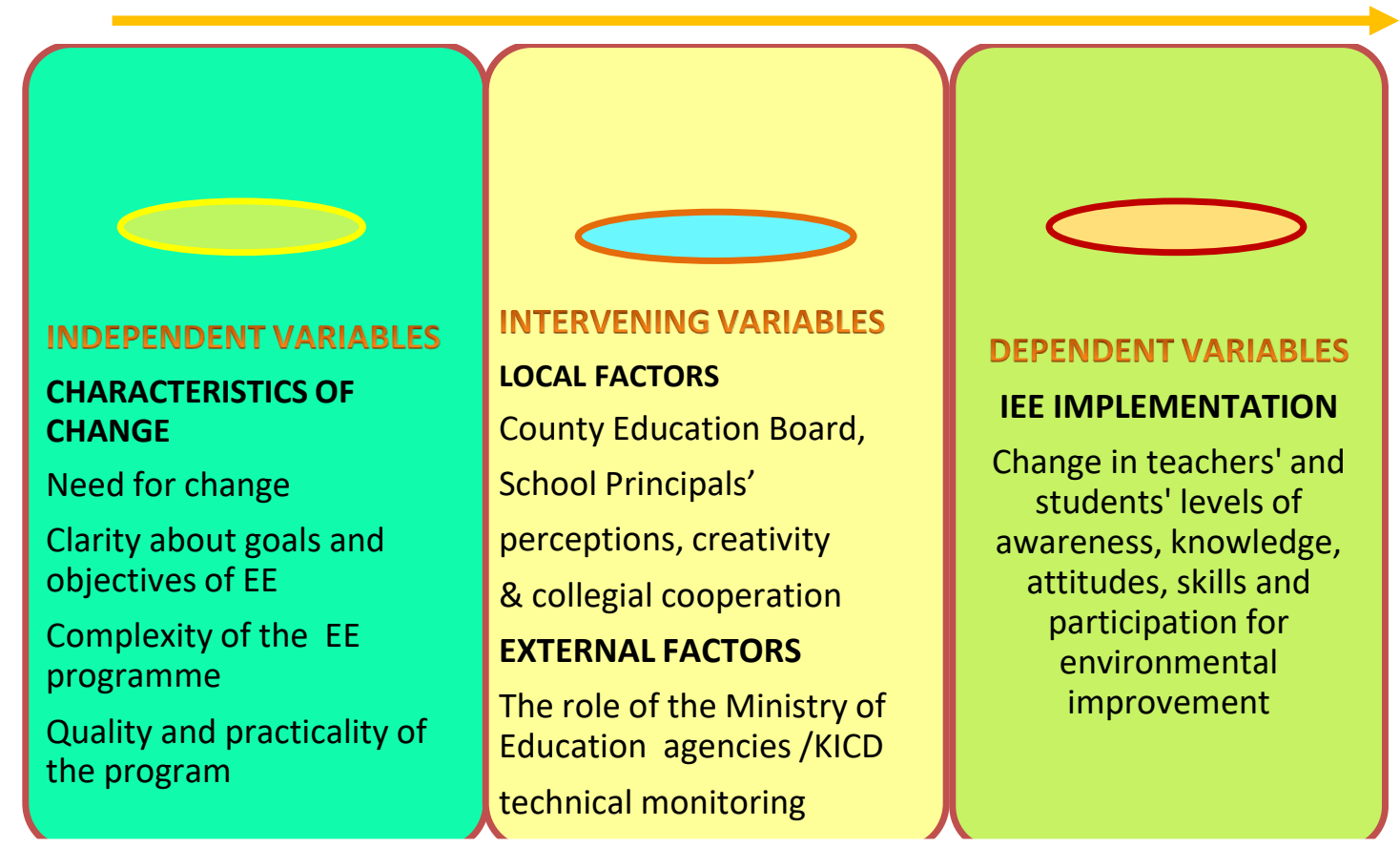

Figure 1 Dynamics of interactions among variables that influence the implementation of an IEE program.

Source: Adapted from Fullan (2007)

Nalzaro (2012) posts that conceptual framework is visual presentation of variables that work together as perceived by the researcher to guide the development of a study. For instance, The Theory of Educational Change views the implementation of IEE programme through lenses of four independent variables identified as need; clarity; complexity; quality and practicality (Figure 1).

The variables network with the intervening variables thus local factors (County Education Board, School Principals' perceptions, creativity \& collegial cooperation) and external factors (The role of the Ministry of Education agencies /KICD technical monitoring) to alter the dependent variables that is teachers' and students' environmental awareness, knowledge, skills, attitudes and participation (Figure 1). In this implementation arrangement, the independent and dependent variables interact through the mediation of intervening variables for technical support, resources and monitoring policies to influence the outcome of IEE implementation process.

\section{Review of Related Literature}

Lasso De Lavega (2004) conducted a study in South West Florida Counties on environmental awareness, knowledge and attitude (AKA) of environmental specialists, high school instructors, students and parents. Study findings indicated that there were no significant differences between high school students and high school instructors regarding pro-environmental attitudes. As regards gender, there was no significant difference in attitudes between sexes across the groups. This seemed contradictory with Rickinson's (2002) assertion that girls were more pro-environmental than boys in their attitudes and behaviours. Study findings also indicated that there were no significant differences between high school instructors and high school 
students regarding AKA. In relation to gender, there was no significant difference between teachers' sexes in terms of environmental literacy.

Poddar (2009) conducted another study on environmental education awareness and attitudes of teachers and students of North-East Chhattisgarh region of India. The study indicated that school teachers possessed attitudes necessary for implementing the integrated environmental education.

Another remarkable study conducted by Kobierska, Tarabuła-Fiertak and Grodzinska-Jurczak (2007) on students' environmental knowledge, behaviour and actions for the benefit of the environment in Poland showed that students had interest and active attitudes to nature and take part in pro-environmental actions. Findings further revealed that contact with nature and the resultant sensitivity (emotions) played a major role in shaping students' pro-environmental attitudes.

Rickinson's (2002) reviews of recent research on students and their learning in school-based environmental education indicated that young people in several countries reported generally positive environmental attitudes and had some involvement in environmental practices influenced by such factors as gender, age, socio-economic grouping, geographical location and schooling. Rickinson (2002) further observes that in terms of gender, girls are more pro-environmental than boys in their attitudes and behaviours.

Ko and Chi-kin (2003) conducted exploratory study of Hong Kong secondary school Integrated Science teachers' perceptions of environmental education. Findings of the study showed that Hong Kong secondary school Integrated Science teachers tended to teach more environmental education if they held more favourable attitudes toward environmental education.

\section{Methodology}

This study adopted quantitative approach and the cross sectional survey design because according to Cohen, Manion and Morrison (2007) cross sectional survey gathers large data at a particular point in time on a one shot basis, hence economical and efficient.

\section{Target Population}

This study targeted sixty four (64) public secondary schools; sixty four (64) public secondary school principals; seven hundred twenty four (724) public secondary school teachers (358 male \& 426 female) and four thousand and thirty (4030) form 4 students in the Sub-County. Data was also collected from four (4) KICD officers in Nairobi County. Additionally, the study targeted chemistry, biology, geography and history subjects as examples of integration points for EE.

\section{Sampling and sample size}

Stratified sampling; simple random sampling and proportionate sampling techniques were employed in selection of thirty (30) secondary schools, 250 secondary school teachers and 360 form four students.

\section{Research Instruments}

Data was collected using document analysis and questionnaires for teachers and students. The questionnaires for teachers and students were structured into three sections thus informed consent for the research participants; background information;

\section{Validity and Reliability of instruments}

Research instruments were dully validated and reliability determined before they were used. Instrument validation employed face and content validity while reliability was determined using Cronbach alpha. The computed reliability coefficients on Likert type items ranged between 0.674 and 0.646 for teachers and students respectively. According to Stack Exchange Inc (2016); George \& Mallery (2003); and Kerlinger (2000) these coefficients were considered to be within the acceptable range of reliability. Based on these results it could be concluded that the instruments were reliable and valid.

Data was analyzed using simple descriptive statistics such as frequencies, percentages, means and standard deviations and presented in tables and diagrams generated by the Statistical Package for Social Sciences (SPSS version 20).

\section{Findings and Discussions}

The researcher investigated attitudes of secondary school teachers and students towards integration of environmental education (EE) in the secondary school syllabus in Machakos Sub County. Data were collected through administering to the respondents ten (10) Likert-type items (5 positive and 5 negative statements). The items were on a five-point scale in which the choices ranged from 1 to 5 . Five (5) points were assigned to "strongly agree", 4 to "agree", 3 to "undecided", 2 to "disagree" and 1 to "strongly 
disagree" However, during data analysis the negative statements were assigned exchange scores, that is Strongly Agree $(S A=1)$, Agree $(A=2)$, Undecided $(U=3)$, Disagree $(D=4)$ or Strongly Disagree $(D=5)$. The higher the score, the more favorable the attitude was towards integration of environmental education and vice versa. Table 2 presents details of the outcome based on the mean scores.

Table 2 Mean scores and standard deviations for each attitude item

\begin{tabular}{|c|c|c|c|c|}
\hline STATEMENT & \multicolumn{2}{|c|}{ Teachers } & \multicolumn{2}{|c|}{ Students } \\
\hline & $\mathrm{M}$ & SD & $\mathrm{M}$ & SD \\
\hline $\begin{array}{l}\text { i. I feel that the benefits that I get from the environment have altered my } \\
\text { attitude towards the environment and its conservation }\end{array}$ & 1.94 & 1.126 & 1.69 & .976 \\
\hline ii. I teach environmental education as well as I do most subjects & 2.76 & 1.164 & 2.70 & 1.307 \\
\hline $\begin{array}{l}\text { iii. Environmental education can help students understand concepts in other } \\
\text { subjects more easily }\end{array}$ & 2.19 & .991 & 1.91 & .932 \\
\hline iv. Environmental topics are logically organized in the syllabus & 3.33 & 1.205 & 2.87 & 1.344 \\
\hline $\begin{array}{l}\text { v. I am willing to volunteer my free time to help out in integrating } \\
\text { environmental concepts and issues in the curriculum }\end{array}$ & 2.29 & 1.013 & 1.86 & .968 \\
\hline vi. Environmental education is an overload in the school curriculum & 3.67 & 1.214 & 3.78 & 1.358 \\
\hline vii. It is demanding to prepare environmental education lessons & 2.97 & 1.280 & 2.49 & 1.322 \\
\hline viii. It is difficult to infuse $\mathrm{EE}$ and requires extensive teacher training & 2.99 & 1.303 & 3.17 & 1.473 \\
\hline ix. Integrated EE is difficult to evaluate & 3.33 & 1.224 & 3.52 & 1.266 \\
\hline $\begin{array}{l}\text { x. Students might not "get integrated EE messages" as they are diluted to fit } \\
\text { the objectives of the carrier subject }\end{array}$ & 2.85 & 1.360 & 3.09 & 1.446 \\
\hline & & & & \\
\hline
\end{tabular}

Key: $\mathrm{M}=$ Mean Score; $\mathrm{SD}=$ Standard Deviation

Source: Field data, 2017

From Table 2, findings indicate that the overall mean score (M 2.83 out of 5) of teachers' attitudes was higher than the students' mean score of (M 2.71 out of 5). These findings could be described as fair attitudes and therefore the respondents seemed to have had a fair conviction of their own role towards integration of environmental education in the secondary school curriculum. The findings concur with those of other scholarly studies carried out by Kumari, Gangwar, Singh, \& Singh's (2012) in India which demonstrated that teachers possessed positive albeit modest attitudes towards both environmental issues and environmental education. The findings also support results for Sarkar's (2011) study on secondary school students' environmental attitudes in Bangladesh which established that overall, students expressed favourable environmental attitudes. However, respondents' attitude mean scores of below 3.0 on a scale of 1-5 is rather unsatisfactory which explains why environmental degradation in Machakos Sub-County is persistent

Although the survey findings indicate that teachers and students were fairly positive about the integrated environmental education, these findings were in conflict with those of Lasso De Lavega (2004) study in South West Florida Counties which indicated that there were no significant differences between high school students and high school instructors regarding pro-environmental attitudes.

\section{Conclusions}

Based on the findings of the study, there is adequate evidence to draw the following conclusions:

Study findings demonstrated that both teachers' and students' attitudes towards integrated environmental education in the secondary school curriculum were fairly positive though not adequate enough for effective 
implementation of IEE in the school curriculum. For this reason, the unrelenting environmental degradation in Machakos Sub-County remains a menace.

\section{Recommendations}

The study recommended that The Ministry of Education and the relevant urgencies such as the Kenya Institute of Curriculum Development (KICD), Directorate of Quality Assurance and Standards (DQAS) and the Kenya National Examinations Council (KNEC) work jointly with school managers to draw an action plan to reinforce and intensify teachers' and students' levels of environmental attitudes through pre-service and in-service training, workshops and seminars on contemporary environmental issues for teachers and promotion of extra-curricular activities linked to nature for students. It is also recommended that studies are undertaken to understand those conflicts in studies on environmental attitudes and the impediments that impede change in teachers' and students' attitudes so that useful and practical interventions can be identified.

\section{REFERENCES}

[1] Adedayo A. and Olawebo J.A. (1997). Integration of Environmental Education in Social Science Curricula at the Secondary school Level in Nigeria: Problems and Prospects. Environmental Education Research, 3(1), 83 - 93.

[2] Ajipoye, O.J. and Silo, N. (2008).Enhancing Botswana children's environmental knowledge, attitudes and practices through the school civic clubs. International journal of environmental and science education.3 (3), 105-114.

[3] Ajzen, I., \& Fishbein, M. (2005). The Influence of Attitudes on Behavior. In D. Albaracn, B. T. Johnson, \& M. P. Zanna (Eds.), the Handbook of Attitudes (p. 173-221). Mahwah, NJ: Lawrence Erlbaum.

[4] Altın, M. 2001. Environment Education in Biology Student Teachers. MA Thesis, Ankara: The Institute of Educational Sciences, the Department of Biology.

[5] Álvarez-García, O., Sureda-Negre, J. and Comas-Forgas, R. (2015). Environmental Education in Pre-Service Teacher Training: A Literature Review of Existing Evidence. Journal of Teacher Education for Sustainability,17(1) pp. 72ñ85,

[6] Baaru, M.W., Gachene, C.K.K., Onwonga, R.N., Mbuvi, J. P. \& Gathaara,V. (2010). Assessment of Changes in Natural Resources: A Participatory Approach. Proceedings of the Second RUFORUM Biennial Meeting held in Entebbe, Uganda, 20 - 24 September 2010.

[7] Bachtiar, S., Zubaidah, S., Corebima, A. D. and Indriwati, S.E. (2018).The Spiritual and Social Attitudes of Students towards Integrated Problem based Learning Models. Issues in Educational Research, 28(2)

[8] Bennett J, Lubben F, and Hogarth S 2007. Bringing Science to Life: A synthesis of the Research Evidence on the Effects of Context-based and STS Approaches to Science Teaching. Sci Educ, 91(3): 347-370

[9] Bhandari, B.B. and Abe, O. (2000). Institute for Global Environmental Strategies. Environmental Education in the Asia-Pacific Region: Some Problems and Prospects. International Review for Environmental Strategies, 1(1), 57 - 77

[10] Chowdhury T. R. (2015).The First Step towards Sustainability: The Practices and Implementation of Environmental Education by Educators in Ontario. Master of Teaching,Ontario Institute for Studies in Education of the University of Toronto.

[11] Chronicle.(2014). Land degradation. [Online] Retrieved from http://www.chronicle.co.zw/landdegradation/

[12] Cohen, L., Manion, L. and Morrison, K. (2007). Research Methods in Education. (6 ${ }^{\text {th }}$ ed.). London and New York: Routledge, Taylor \& Francis Group:

[13] Engin, A. (2003). Science and Biology Student Teachers ${ }^{e e}$ Environment Education and Attitudes before and after their Ecology Course Experience. MA Thesis, İstanbul: Marmara University, The Institute of Educational Sciences.

[14] Erol, G.H. (2005). Elementary Education Department 2nd Year Students' Attitudes towards Environment and Environmental Problems. MA Thesis, Denizli: Pamukkale University, the Institute of Basic and Applied Sciences. 
[15] Erten, S. Özdemir, P. and Güler, T. (2003). Determination of the Pre-school Teachers' Levels of Environmental Awareness and the Status of Environmental Education in these Schools. Proceedings from the OMEP 2003 World Council and Conference, Turkey (2), 334-350.

[16] Esa N.(2010) Environmental Knowledge, Attitude and Practices of Student Teachers. International Research in Geographical and Environmental Education 1(19) [Online] Retrieved on July 292018 from https://doi.org/10.1080/10382040903545534

[17] Fullan, M. (2007). The New Meaning of Educational Change. (4 ${ }^{\text {th }}$ Ed.) New York: Teachers College Press.

[18] Fullan, M. (2001). Leading in a culture of change. San Francisco: Jossey-Bass.

[19] George, D., and Mallery, P. (2003). SPSS for Windows step by step: A simple guide and reference. 11.0 update (4thed.). Boston: Allyn \& Bacon.

[20] Greve, W. (2001). Traps and gaps in action explanation: Theoretical problems of a psychology of human action. Psychological Review, 108, 435-451.

[21] Hammonds, B. (2002). The New Meaning of Educational Change by Michael Fullan 2001. Leading and Learning for the $21^{\text {st }} 3$ (1). [Online] Retrieved from file:///F:/vol01-no03-2002.html. Email: bhammonds@leading-learning.co.nz

[22] Hashemzadeh. F.(2016). Environmental Awareness, Attitudes, and Behaviour of Secondary School Students and Teachers in Tehran, Iran. Doctoral thesis, The University of Waikato, New Zealand

[23] Hassan, A., Abd Rahman, N. \& Abdullah, S. I. S. S. (nd). The Level of Environmental Knowledge, Awareness, Attitudes and Practices among Universiti Kebangsaan Malaysia Students. Email: arbaat@yahoo.com

[24] Hungerford HR, Peyton RB, Wilke R.(1980).Goals for Curriculum Development in Environmental Education. J Environ Educ, 11(3): 42-47

[25] International Fund for Agricultural Development (IFAD). (2007).Combating Environmental Degradation. Retrieved December 1, 2009. (http://www.ifad.org/events/past/hunger/envir.html).

[26] Jan Činčera, B. J. (2015) Examining the Relationship between Environmental Attitudes and Behaviour in Education Programmes . Sociální studia. Department of Sociology FSS MU, 3/2015. S. 97-111. ISSN 1214-813X.

[27] Jenny MA, Hanrahan, J. (2002) Teachers' Attitudes toward Integration in Hong Kong. EducationJournal( 教育學報), 1(30) p 63-77

[28] Jian S. (2004). Problems and Countermeasures Facing "Green School" Creation. Chinese Education and Society, 37(3), 71-77. M. E. Sharpe, Inc. ISSN 1061-1932 / $2004 \$ 9.50+0.00$.

[29] Kahriman-Ozturk D, Olgan R, Tuncer G 2012. A qualitative study on Turkish preschool children's environmental attitudes through ecocentrism and anthropocentrism. Int J Sci Educ, 34(4): 629-650

[30] Kandýr A, Yurt O, Cevher-Kalburan N (2012). Comparison of teachers and teacher candidates in terms of their environmental attitudes. Educ Sci Theor Pract, 12(1): 323-327).

[31] Keaney, M.T. (nd) Examining Teacher Attitudes toward Integration: Important Considerations for Legislatures, Courts, and Schools. Saint Louis University Law Journal Vol. 56:827

[32] Kelani, R. R. (2015). Integration of Environmental Education in Science Curricula in Secondary Schools in Benin, West Africa: Teachers' Perceptions and Challenges. Electronic Journal of Science Education. 19(3), 1-24. [Online]. Retrieved from http://ejse.southwestern.edu /article/view/14464

[33] Keleş, Ö. (2017). Investigation of Pre-Service Science Teachers' Attitudes towards Sustainable Environmental Education. Higher Education Studies; 3(7) pp171-180 [Online] Retrieved on July 29 2018 from URL: http://doi.org/10.5539/hes.v7n3p171

[34] Kerlinger F. N. \& Lee (2000). Foundations of Behavioral Research. (4 $\left.4^{\text {th }} \mathrm{ed}\right)$. Orlando: Harcourt Inc

[35] Kimaryo L. A. (2011). Integrating Environmental Education in Primary School Education in Tanzania. Teachers' Perceptions and Teaching Practices. Åbo: Åbo Akademis Förlag - Åbo Akademi University Press.

[36] Ko and Chi-kin (2003) Teachers Perceptions of Teaching Environmental Issues within the Science Curriculum: A Hong Kong Perspective. Journal of Science Education and Technology, 3 (12), pp.187204[Online] Retrieved on June 62013 from /http://www.jstor.org/stable/40188766

[37] Kobierska, H. Tarabuła-Fiertak, M. and Grodzinska-Jurczak, M. (2007). Attitudes to Environmental Education in Poland. Journal of Biological Education, 42(2), 12-18 
[38] Koskey J. R. (2013). Resource Provision, Stakeholder Attitudes, and Support for National Centre for Early Childhood Education (NACECE) Curriculum Implementation in Uasin Gishu County, Kenya. International Journal of Advanced Research (2013), Volume 1(3), 354-361. Retrieved from Journal homage: http://www.journalijar.com

[39] Kryptone Consulting Limited. (2012). Baseline Survey Report for Katoloni CBO On Kiima Kimwe Hills and Associated River Basin Conservation Project. [Online] Retrieved on March 182015 from http://kryptoneconsultinglimited.weebly.com

[40] Kumari, S., Gangwar, R. K., Singh, J., Singh, A.P. (2012). Assessment of Environmental Awareness and Attitude among the School Teachers in Bareilly City. International Journal of Innovative Research and Development 8 (1), 486-492. [Online].Retrieved from www.ijird.com October, 2012, on May 102016

[41] Lasso de la Vega, E. (2004). Awareness, Knowledge, and Attitude about Environmental Education: Responses from Environmental Specialists, High School Instructors, Students, and Parents. Doctoral dissertation in curriculum and instruction, University of Central Florida, Orlando, Florida.

[42] Masila, S. M. (2016). Effects of Land Degradation on Agricultural Land Use: A Case Study of Smallholder Farmers Indigenous Knowledge on Land Use Planning and Management in Kalama Division, Machakos County. Master of Science Thesis, South Eastern Kenya University

[43] McGuire, N. M. (2015). Environmental Education and Behavioral Change: An Identity-Based Environmental Education Model. International Journal of Environmental \& Science Education, 2015, 10 (5), 695-715 [Online] Retrieved on August 15, 2016 from ijese.2015.261a.pdf

[44] Mwanza, Z.N. (2016). Teachers' and Pupils' Perceptions of Environmental Education in selected Primary Schools of Chipata District of Eastern Zambia. Master of Education, University of Zambia

[45] Myers G, Boyes E, Stanisstreet M (2004). School Students' Ideas about Air Pollution: Knowledge and Attitudes. Res Sci Tech Educ, 22: 133-152).

[46] Nalzaro, L. M. (2012). Chapter 6- Theoretical \& Conceptual Framework [Online] Retrieved from file:///E:/Chapter 6-Theoretical \& Conceptual Framework.html

[47] Null, W. (2011). Curriculum from Theory to Practice. Toronto: Rowan and Littlefield Publisher, Inc

[48] Odeke, E. J .G. (2009). Contextualising Curriculum through Issues Based Approaches: A Case of Eco-Schools in Kenya. Masters Thesis, Rhodes University

[49] Özden, M. (2008). Environmental awareness and attitudes of student teachers: An empirical research. International Research in Geographical and Environmental Education. 17 (1): 40-55.

[50] Plombon, E. (2011). Factors Affecting Pro-Environmental Attitudes. UW-L Journal of Undergraduate Research XIV pp 1-14

[51] Poddar, A. K. (2009). An Assessment of Environmental Education in Primary Schools of North-East Chhattisgarh Region with reference to Environmental Awareness and Attitude of Teachers and Students' in Abstracts of Research Studies Conducted by Teacher Education Institutions in India Volume III D.R. Goel, Chhaya Goel, R.L. Madhavi CASE, The M.S. University of Baroda, Vadodara - 390002

[52] Prati, G., Albanesi, C., and Pietrantoni, L. (2017). The interplay among environmental attitudes, proenvironmental behavior, social identity, and pro-environmental institutional climate. A longitudinal study. Environmental Education Research, 23(2), 176 - 191. Presented at the 2017/02/07/. Retrieved from $\underline{\mathrm{http}} / / / \mathrm{dx}$.doi.org/10.1080/13504622.2015.1118752 (link is external)

[53] Republic of Kenya. (2013). Integrated Programme to Build Resilience to Climate Change and Adaptive Capacity of Vulnerable Communities in Kenya. National Implementing Entity -NEMA KENYA. Nairobi: Government Printer

[54] Rickinson, M. (2001/2). Environmental Education: Recent Research on Learners and Learning. The Mere, Upton Park, Slough SL1 2DQ. Email: m.rickinson@nfer.ac.uk

[55] Rogers, E. M. (2003) Diffusion of innovations (5th ed.) New York: The Free Press

[56] Said AM, Ahmadun F, Paim LH, Masud J (2003). Environmental Concerns, Knowledge and Practices Gap among Malaysian Teachers. Int J Sustain High Educ, 4: 305-313;

[57] Sarkar, M. (2011). Secondary Students' Environmental Attitudes: The Case of Environmental Education in Bangladesh. International Journal of Academic Research in Business and Social Sciences, Vol. 1, Special Issue ISSN: 2222-6990 
[58] Stack Exchange Inc. (2016). Where do the descriptors for Cronbach's alpha values come from (e.g., poor, excellent) [Online] Retrieved on December 14, 2016 from

[59] http://stats.stackexchange.com/questions/70274/where-do-the-descriptors-for-cronbachsalpha-values-come-from-e-g-poor-exce

[60] Strong C. (1998). The Impact of Environmental Education on Children's Knowledge and Awareness of Environmental Concerns. Market Intell Plann, 16: 349-355

[61] Taskin,O. (2009). The Environmental Attitudes of Turkish Senior High School Students in The Context of Postmaterialism and The New Environmental Paradigm", International Journal of Science Education, 31(4), 481-502

[62] Toili, W.W. (2007). Secondary school students' participation in environmental action:

a. Coercion or dynamics? Eurasia Journal of Mathematics, Science \& Technology Education 3(1), 51-69.

[63] Ugulu I., Sahin, M. and Baslar, S. (2013) High School Students' Environmental Attitude: Scale Development and Validation. Int J Edu Sci, 5(4): 415-424

[64] Ugulu I, Erkol S (2013). Environmental Attitudes of Biology Teacher Candidates and the Assessments in Terms of Some Variables. NWSA-Education Sciences, 8(1): 79-89).

[65] Ünal, N. (2008). Pre-Service Teacher's Perceptions toward Global Versus Local Environmental Issues. Master of Science Thesis, Middle East Technical University

[66] UNESCO-UNEP 1991, Changing Minds Earthwise. Connect, 23: 1-69).

[67] United Nations.(2015).United Nations Global Issues. Climate Change. [Online]Retrieved on April 7 2015 from www.un.org/en/aboutun/copyright/

[68] Upadhyay, A. (nd) Role of environmental attitudes in sustainable development: A study from an ESD and a conventional neighbourhood. The University of Sydney, CER symposium Precarious Times: New Imaginings for Sustainability

[69] Vlaardingerbroek, V., T.G. Neil Taylor, T. G. 2007. The Environmental Knowledge and Attitudes of Prospective Teachers in Lebanon: A comparative study. International Research in Geographical and Environmental Education, 16 (2): 120-134.

[70] Waswa, B. S. (2012). Assessment of Land Degradation Patterns in Western Kenya: Implications for Restoration and Rehabilitation. Dissertation,University of Bonn. [Online] Retrieved on April 82015 from http://hss.ulb.uni-bonn.de/diss_online elektronisch publiziert

[71] Westmoreland-King, E. (2012). The Implementation of Environmental Education (EE) Programs on School Grounds in pre-K-12 Schools in Colorado: From Gardens to Solar Energy. PUAD 5361: Advanced Seminar in Public Policy and Management. Martell, C., Madden, A., Six, J. ( Eds). Alliance for Sustainable Colorado

[72] Wright, M. and Klÿn, B. (1998). Environmental Attitude - Behaviour Correlations in 21 Countries. Journal of Empirical Generalisations in Marketing Science, Volume Three, p42-60

[73] Yorek N, Ugulu I, Sahin M, Dogan Y 2010. A qualitative investigation of students' understanding about ecosystem and its components. Natura Montenegrina, 9(3): 973-981) 